\title{
Vulnerability Assessment of Reinforced Concrete Building Subjected to Seismic Loads Using Pushover Analysis
}

\author{
Endah Wahyuni $^{1}$, Data Iranata ${ }^{1}$, and Heppy Kristijanto ${ }^{1}$
}

\begin{abstract}
Buildings should be designed to withstand an earthquake based on earthquake planning standard. However, the references used in the regulation could not show building performance to the actual earthquake directly. Therefore, it required an assessment of the existing buildings, in order to evaluate their vulnerability (structural performance level). This study discussed the vulnerability assessment of reinforced concrete buildings from the analysis of the relationship between base shear and displacement, and any failure that occurred. The first step of the evaluation was analyzed the seismic loads with Static Nonlinear (Pushover) Analysis using SAP2000 software. The pushover analysis results showed the level of damage to assess the building damages. This research was based on SNI 03-1726-2002, Federal Emergency Management Agency (FEMA) 273/356, FEMA 440, and the Applied Technology Council (ATC)-40. Displacement values obtained from Pushover Analysis compared with the field studies. From the pushover analysis, the results obtained the capacity curve showing the relationships between the base shears and the displacements, reviewed at each elastic conditions, ultimate, plastic and collapse. The numerical results turned out to be closed to the performance level of the structure in the field. Thus the analysis can be used as a reference on an assessment level of performance and behavior of the existing structure as well as the vulnerability of the structure.
\end{abstract}

Keywords—Earthquake Resistant Buildings, Nonlinear Static Pushover Analysis, Curve Capacity, Performance Structure.

\section{INTRODUCTION}

$\mathrm{E}$ arthquake is a natural disaster that can destroy building fasility and other important facility. The earthquake's deterioration had shown how suffer we had. Buildings that located in the center of earthquake sometimes become vulnerable when quakes coming in, particularly the risk of major damage or casualties will be suffered people inside the building. Therefore, an assessment is required to evaluate the vulnerability (structure performance level) of the building, which regulated in FEMA (Federal Emergency Management Agency) 356.

Non-linear static (pushover) analysis is an analysis procedure to find out building's collapse subjected to the earthquake. This analysis is conducted by providing statics lateral load pattern to its structure, increased steps with factors to the lateral movement target from accomplished [2]. The pushover process can be done by load or displacement controller procedure. The displacement that derived from numerical analysis with pushover analysis are compared to prior field research results to find out the building performance.

The objective of this research is to analyse a reinforced concrete building vulnerability. The modelling of reinforced concrete buildings used SAP 2000 software.

First analysis is to check the dimension of structural elements; then using the non-linear analysis to find out the capacity of the elements and performance level based on FEMA 356.

\section{EXPERIMENTAL RESULTS}

Two story school building is selected as a case study to assess the reinforced concrete building. The building

${ }^{1}$ Endah Wahyuni, Data Iranata, and Heppy Kristijanto are with Departement of Civil Engineering, Faculty of Civil Engineering and Planning, Institut Teknologi Sepuluh Nopember, Surabaya, 60111, Indonesia. E-mail: endah@ce.its.ac.id; data@ce.its.ac.id; heppy_ftsp@yahoo.com. located is in a low seismic zone. According to material tests, the compressive strength of concrete of fc ' is 15.1 $\mathrm{MPa}$, and the yielding strengths of longitudinal steel bar and transverse reinforcement are 287.2 $\mathrm{MPa}$ and 477.2 $\mathrm{MPa}$, respectively. The ultimate strengths of longitudinal steel bar and transverse reinforcement are $425.5 \mathrm{MPa}$ and 678.1 MPa, respectively. The building height of each storey is $3.6 \mathrm{~m}$. The plan view of the building and its model with SAP2000 are shown in Figures 1 and 2 respectively.

The building was tested with a lateral loading on top storey. Using the displacement targets from $0.25 \%$ to $5 \%$, the base shear of the building found out. The field test results, which shown the relationship among the displacement target (\%), roof displacement (mm) and base shear (ton), is shown in Table 1.

\section{PUSHOVER ANALYSIS}

Nonlinear static analysis is an analysis procedure to know the building collapse behavior toward earthquake, also known as pushover analysis or push load static analysis. Except for a simple structure, so this analysis need computer program in order to able to realization it to the real building. The analysis is done by giving a lateral load static pattern on the structure, which then gradually increased with a multiplier factor to a target lateral displacement from a reference point is reached. Usually the point is a point on the roof, or more precisely, is the center of mass of the roof. Pushover analysis produces pushover curve. The curve describing the relationship between base shear force (V) versus displacement of reference point of the roof (D).

Capacity curve will show a linear condition before reaching the plastis point and subsequent non-linear behavior. Pushover curve is influenced by the lateral force distribution patterns used as thrust loads. The purpose of pushover analysis is to estimate the maximum force and deformation and to obtain information on which parts are critical. Furthermore it is able to identifiable parts that require special attention to detail or 
stability. Pushover analysis can be used as a tool for earthquake resistant design, provided that conforms with the existing limitations, that is:

a. Results still be a pushover analysis approach, because however the actual behavior of the earthquake is to be back and forth through a particular cycle, while the nature of loading on the static monotonic pushover analysis.

b. Selection of the lateral load pattern used in the analysis is very important.

c. To create a model of nonlinear analysis would be more complicated than the linear analysis model. The model must take into account the inelastic loaddeformation characteristics of the elements that are important and the P- $\Delta$ effects.

\section{A. Loading}

To check the capacity of the elements, the dead, live and earthquake loads applied on the building. The load combination based on the Indonesian standard was carried out too on the building. The values of the load as explained follows:

1) Dead Load (DL)

a. Self weight (SW) calculated automatically by the SAP2000 program

b. Super Imposed Dead Load (SIDL):

1.1st Floor

$\begin{array}{ll}\text { MEP } & : 0.10 \mathrm{kN} / \mathrm{m} 2 \\ \text { Ceramic } & : 0.24 \mathrm{kN} / \mathrm{m} 2 \\ \text { Spesi } & : 0.21 \mathrm{kN} / \mathrm{m} 2 \\ \text { Roof floor } & : 0.10 \mathrm{kN} / \mathrm{m} 2 \\ \text { MEP } & : 0.05 \mathrm{kN} / \mathrm{m} 2\end{array}$

c. Clay brick : $2.5 \mathrm{kN} / \mathrm{m} 2$

d. Concrete wall : $24 \mathrm{kN} / \mathrm{m} 3$

2) Live Load (LL)

Floor $\quad=2.5 \mathrm{kN} / \mathrm{m} 2$

Roof $\quad=1.0 \mathrm{kN} / \mathrm{m} 2$

3) Earthquake Load (E)

Referred to Indonesia seismic code (RSNI-1726-2010), the building is located in the low zone with the values of $\mathrm{S}_{\mathrm{s}}$ and $\mathrm{S}_{1}$ as shown in Figures 3 and 4 . Using these diagram and other coefficients, the respon spectrum in this area can be calculated.

\section{B. Limit Service and Ultimate Performances}

Limit service performance of the building structure is determined by inter-level due to the influence of Earthquake Plan, namely to restrict the occurrence of melting steel and cracking concrete is excessive, in addition to preventing non-structural damage and occupant discomfort. Deviation between these rates should be calculated from the deviation of the building structure due to the influence of earthquake which has been divided Nominal Scale Factor.

Limit ultimate performance of the building structure is determined by the deviation and maximum deviation of inter-level buildings due to earthquake effects in the structure of the building plan on the verge of collapse, it is for limited the possibility of collapse of building structures that can cause human casualties and to prevent harmful impact of inter-building or between parts of the building structure which is separated with interrupted separator. So there are 2 kinds of deviation limit deviation (drift), namely: a. (1). Limit Service Performance of the structure (UBC 1997 calls $\Delta \mathrm{s}$ )

b. (2). Limit Ultimate Performance of structure $(\Delta \mathrm{M})$

Both values of the building can be seen in Tables 2 and 3 respectively.

Limit Service Performance shall be calculated in nominal terms due to loads modeling, whereas ultimate limit of performance of the structure is in-elastically maximum deviation due to load obtained by multiplying $\Delta$ s plan with a multiplier factor $\xi=0.7 \times \mathrm{R}$ for irregular buildings.

In the design of earthquake resistant structures, deviation $(\Delta M)$ between the levels must not exceed 0.02 times of the height of the relevant level to limit the possibility of collapse of building.

\section{Performance Level}

The performance purpose is divided into Structural Performance Level (SP-n, where $\mathrm{n}$ indicates the number) and Non-structural Performance Level (NP-n, where n indicates the letter). This can be specified individually, however, a combination of both determines the overall performance level of the building.

Structural performance levels of the building are:

a. Immediate occupancy (SP-1): the limit of damage structural with the vertical base style and resistance system of lateral style most of the character and its capacity before the earthquake.

b. Damage control (SP-2): the condition of the damaged somewhere between the Immediate Occupancy and Life Safety.

c. Life safety (SP-3): the significant damage to some edge of either total or partial collapse. Disadvantages occur with low-risk threat to safety. Recovery is not economically feasible.

d. Limited safety (SP-4): the condition where the damage is between Life safety and structural stability.

e. Structural stability (SP-5): structural damage in large numbers in which the system structure on the boundary of experiencing some or whole collapsed. The big risk is still exists. Recovery is not possible both technically and economically.

f. Not considered (SP-6): The situation where only does the evaluation of non-structural or seismic retrofit.

The end result is given a base shear to produce the movement of its structure. The value will be described in a capacity curve form that represent of structure manner in lateral movement to load (demand) that provided as shown in Figure 5. Figure 12 shows the pushover analysis results. In addition, the pushover analysis can perform structure elements that suffer a failure visually.

The performance point is reached to turnover 70,447 $\mathrm{mm}$ and base shear of 110,801 tons. The ultimate limit performance according to SNI 03-1726-2002 based on numerical analysis, the maximum roof turnover $\mathrm{X}$ direction is $0,026 \mathrm{~m}$, ultimate drift that occurs:

s.X

$\varsigma=0,7 \mathrm{R}$

$\zeta=0,7 \times 3,5=2,45$

Thus, ultimate drift at $\mathrm{x}$ direction is $0,026 \times 2,45=$ $0,064 \mathrm{~m}$. Table 4 shows the summary of performance points using spectrum capacity method, displacement 
coefficient method from FEMA 356 and FEMA 440, and according to Indonesian standard.

The maximum displacement target is $0,127 \mathrm{~m}$ based on FEMA 356 and FEMA 440 as shown in Table 4. It can be concluded that when the maximum displacement target occurs, the structure were at LS - CP (Life savety to Collapse Prevention).

\section{Assesment OF PERFORMANCE LEVEL}

The comparison of capacity curve from Pushover analysis from numerical and field testing is shown in Figure 6. As shown in the figure, both graph is quite close one to other.

\section{A. First Condition - Elastics}

Based on pushover analysis results on Figure 7 is proven that plastics joint beginning to happen to most of top beam and column, the building is include B-IO category (Operational Level towards Immediate Occupancy Level) which means that were in medium application level and suffers displacement of 21,61 mm with baseshear of 89,51 tons. Based on FEMA 356 the condition shows an indicator that the building have no alteration permanently, in this case the building is in elastic condition. The structure still have a rigid and suffers light damage namely hair crack on column, beam and partial walls. Similar displacement alteration on field test result namely 18,39 mm with 90 tons baseshears could be seen on Figure 7 where the structure has also have similar damage namely hair crack on column and the column have no major alteration. Based on fact above it can be concluded that pushover static analysis result in structure performance description that approach with field test condition by the displacement percentage value differences of $85,1 \%$ and base shear of $99,45 \%$.

\section{B. Second Condition - Ultimate}

Pushover analysis result on second condition (step 5) show in Figure 8 that plastic joint is occuring at top of beam and most of the base column, the building is still in B-IO category (Operational Level towards Immediate Occupancy Level) where it means posing at medium application but have an elasticity by having displacement of 55,97 mm with base shear 109,57 tons. The building structure have no permanent deviation but only suffers minor damage namely hair crack at column, beam and partition wall. Along with displacement alteration of field testing results of $36,78 \mathrm{~mm}$ with base shear 114 tons can be seen in Figure 8 the structure has also suffered the same damage namely hair crack to column, beam and partition wall. The column has not also suffered big deviation. It can be concluded that pushover static analysis give result of structure performances description that approaching with field testing condition by displacement percentage score of $65,72 \%$ and base shear $96,11 \%$.

\section{Third Condition - Plastic}

Pushover analysis result on third condition (Step 9) in Figure 9 shows that plastic joint are suffers through top of beam and column, the building consist of IO - LS category (Immediate Occupancy Level towards Life Safety) which means the building suffering the damage but the structure remains stabil, the damage remain controlled and under safe level to be resided by having a displacement of 70,54 mm with base shear of 110,76 tons. The structure still have a rigidity and suffers only mild damage namely hair crack on column, beam and partition wall, a little spelling in few column and crack to several column joint. With field testing displacement alteration result namely $73,55 \mathrm{~mm}$ with 115 tons baseshear could be seen in Figure 9 prove that a few column had suffered huge damage which is marked with transparent crack. Based on that it could be concluded that pushover static analysis result in light different performance structure description with building physical damage with field test condition by displacement percentage value of 95,9\% and base shear 96,31\%.

\section{Fourth Condition - Structure Stability}

In the Figure 10 pushover analysis result on fourth condition (step 13) shows that plastic joint run in through top of beam and column, the building had already experiencing structure stability where its ability in receiving the load is already subsided. Beginning LS-C cateogry (Life Safety Level towards Collaps) which means the building remain stand up and the damage or any other lose are still allowed with a few structure restoration. The structure had displacement of 143,52 $\mathrm{mm}$ with 110,19 tons baseshear, the permanent deviation, several column suffers serious damage which is marked by transparent crack. With $147,1 \mathrm{~mm}$ field testing displacement result and base shear 102 tons can be previewed in Figure 10 a slight different in pushover analysis where the structure have permanent deviation with severe damage in few column that marked by slide crack. Looking at previous conditions, base shear that hold in lateral is keep power is reducing which means the structure has approaching collapsing point. Based on that statement, it could be concluded pushover static analysis can result in little different of performance structure description with physically damage by taking field test condition where part of column had severe joint damage with displacement percentage value differences of 97,57\% and 92,57\% baseshear.

\section{E. Fifth Condition - Collapse}

Pushover analysis result in fifth condition (Step 18) in Figure 11 shows that the structure has entering collapse category which means that most building have experiencing a collapse. The structure is falling down to displacement of 289,52 mm with 12,06 tons base shear. By taking a field test result of displacement alteration namely $376,75 \mathrm{~mm}$ with 33 tons base shear can be seen in Figure 11, the structure has also experiencing fall down on its ground floor, so as the building can no longer be used. Based on that it concluded that pushover static analysis result a performance structure description that nearing to field test condition by the displacement percentage value of $76,85 \%$ and $36,54 \%$ base shear.

\section{CONCLUSION}

1. From the analysis of field testing and compared with numerical static pushover analysis, vulnerability assessment can be carried out with the following results:

a. Elasticity analysis showed that the structure is able to support the weight of the load received, both gravity and seismic loads have been 
combined. However, the structure does not meet the requirements of beam-column relations.

b. Based on the results of numerical analysis pushover and field testing, it was found that damage from the first plastic hinge occurs at the base of the beam is then up to the base of the column.

c. Collapse occurs at 1 st floor columns. The pattern collapse is not good, because it should collapse first occurred in the beam which is then followed by the collapse of the column.

d. From the studies that have been done, it can be concluded that the numerical analysis of the static pushover nonlininier produce structural behavior of each elastic conditions, the ultimate, the plastic, the stability of the structure to collapse under review closer to real conditions in the field, so that the analysis can be used as a reference as an assessment level of performance and behavior vulnerability of existing structures.

2. From the field testing result comperation with pushover analysis result, at the elastically condition displacement differences of $85.1 \%$ and $99.45 \%$ base shear, at the ultimate condition displacement differences of $65.71 \%$ and $96.11 \%$ base shear, on the condition of plastic displacement differences of
95.9\% and $96.31 \%$ base shear, on the structure stability displacement differences of $97.57 \%$ and 92.57\% based shear and the conditions collapsed displacement differences of $76.85 \%$ and $36.54 \%$ base shear. Overall average of each differences obtained test results with the numerical analysis of $84.21 \%$.

\section{ACKNOWLEDGEMENT}

We would like to acknowledge the financial support provided by and ITS research grants under DGHE research grant to conduct this research.

\section{REFERENCES}

[1]. Briceño, S ; Onogawa, K. 2009. Mengurangi Kerentanan Anak Anak Sekolah terhadap Bahaya Gempa Bumi. Pusat Pembangunan Wilayah Perserikatan Bangsa - Bangsa (UNCRD). Proyek Inisiatif Keselamatan Sekolah Terhadap Gempa Bumi (SESI)

[2]. Dewobroto, W. 2005. Evaluasi Kinerja Bangunan Baja Tahan Gempa dengan Analisa Pushover. Civil Engineering Nationa Conference : Sustainability Construction \& Structural Engineering Based on Professionalism, Unika Soegijapranata, Semarang, Indonesia.

[3]. Wahyuni, E; Iranata, D, Widodo, A and Irawan D, 2013. Evaluasi Kerentanan Gedung Sekolah Dasar Beton Bertulang Dua Lantai Pascagempa. Prosiding Seminar Nasional Teknik Sipil IX, 2013, Surabaya 6 Februari 2013.
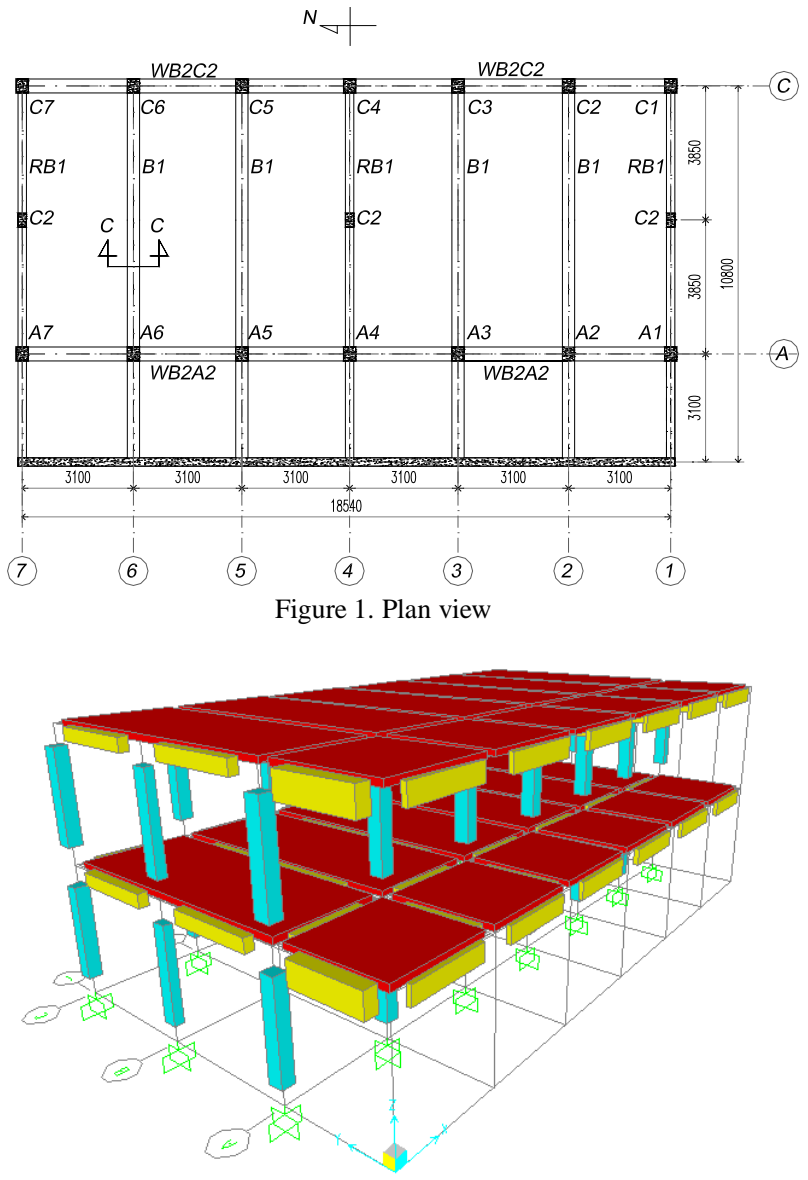

Figure 2. Modelling of the building

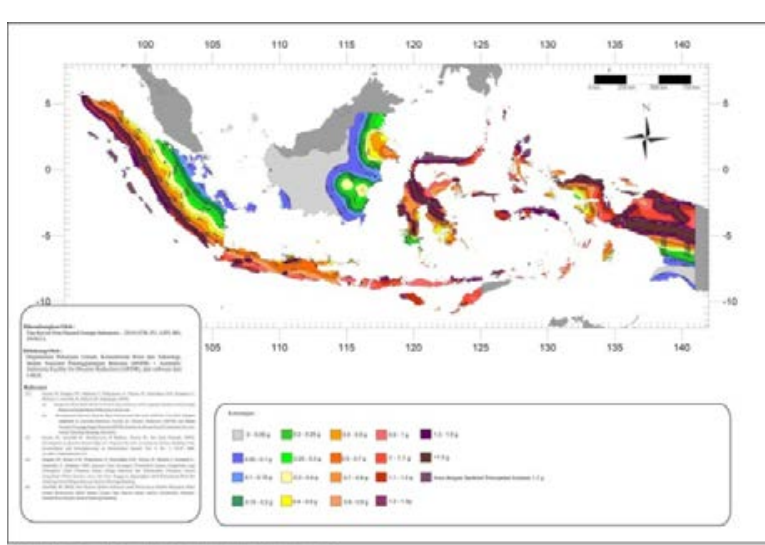

Figure 3: Seismic zone, Ss (SNI-1726-2010)

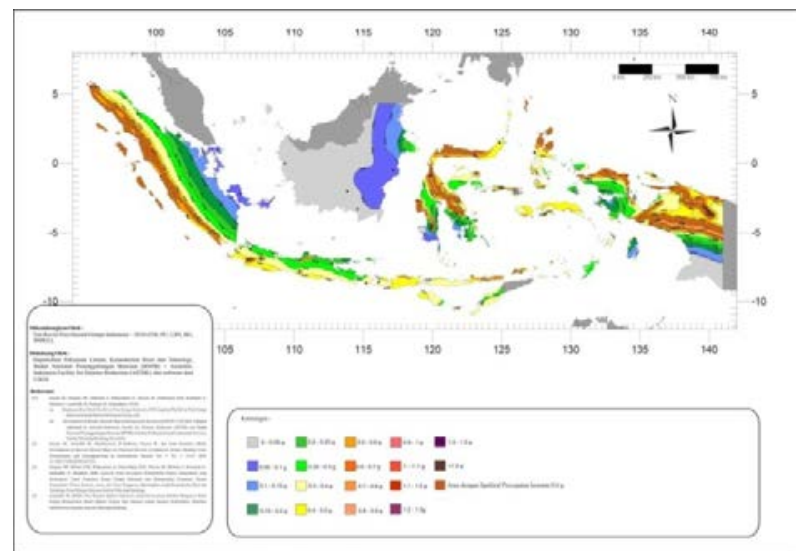

Figure 4: Seismic zone, s1 (SNI-1726-2010) 


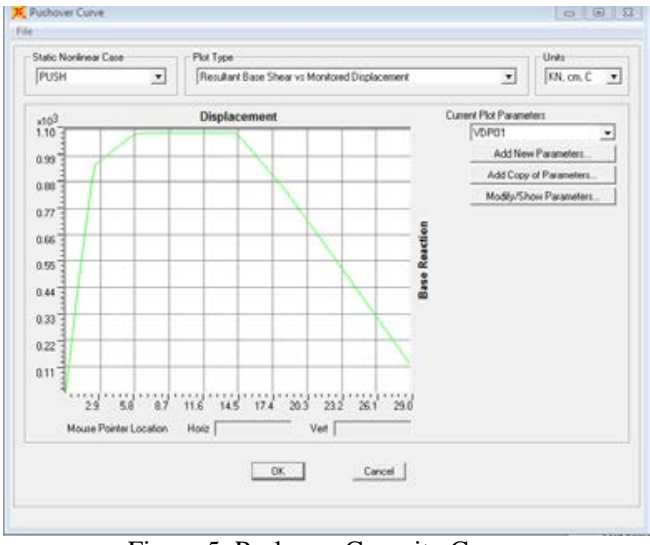

Figure 5. Pushover Capacity Curve

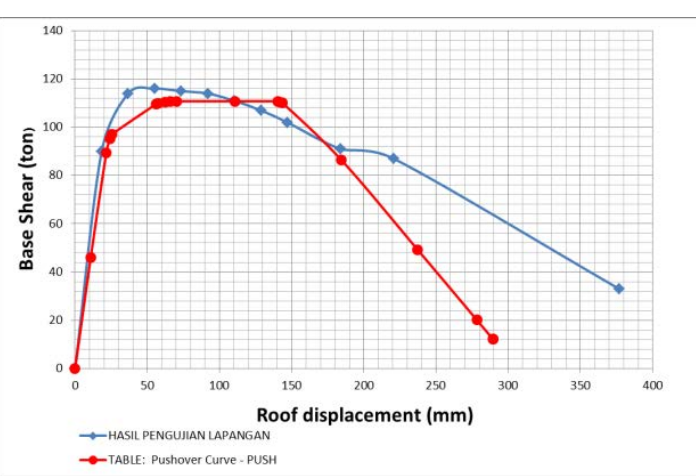

Figure 6. Comparison of base shears and roof displacements from numerical analysis and field testing

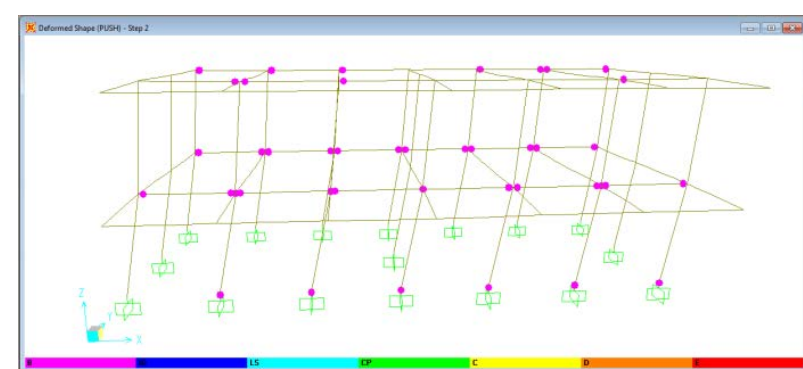

Figure 7. Scheme of plastic hinges distribution in the first condition (step 2)

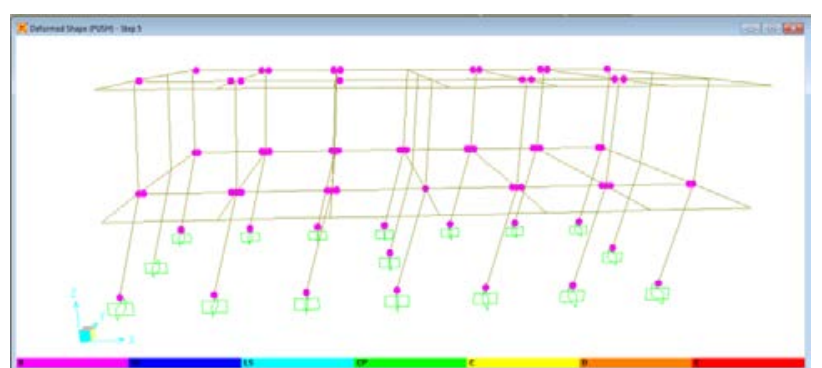

Figure 8. Scheme of plastic hinges distribution in the second condition (step 5)

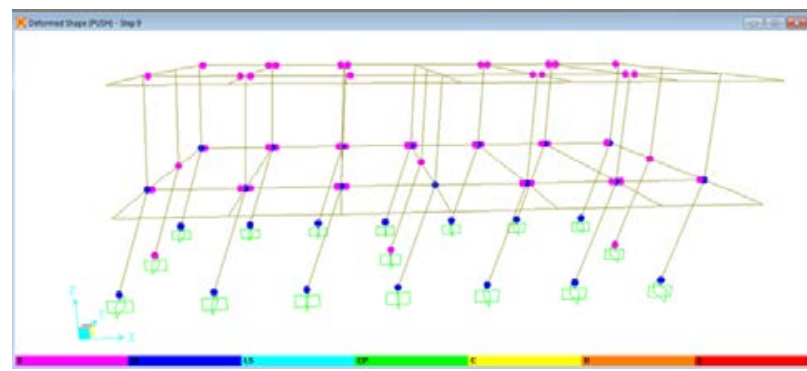

Figure 9. Scheme of plastic hinges distribution in the third condition (step 9)

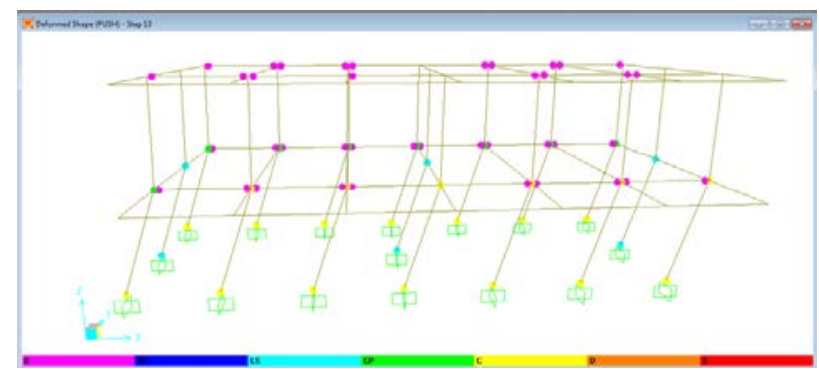

Figure 10. Scheme of plastic hinges distribution in the fourth condition (step 13)

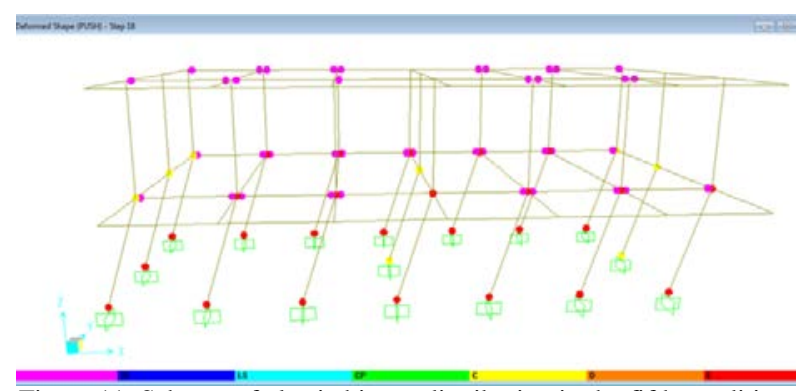

Figure 11. Scheme of plastic hinges distribution in the fifth condition (step 18)

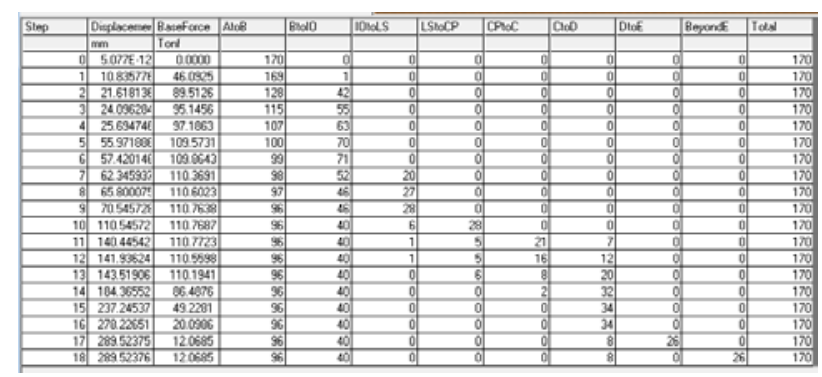

Figure 12. Pushover analysis results

TABLE 1.

BuILDING TESTING RESULTS

\begin{tabular}{ccc}
\hline \hline $\begin{array}{c}\text { Displacement } \\
\text { Target } \\
\mathbf{( \% )}\end{array}$ & $\begin{array}{c}\text { Roof } \\
\text { Displacement } \\
\text { (mm) }\end{array}$ & $\begin{array}{c}\text { Base } \\
\text { shear } \\
\text { (Ton) }\end{array}$ \\
\hline 0 & 0 & 0 \\
0.25 & 18.39 & 90 \\
0.5 & 36.78 & 114 \\
0.75 & 55.16 & 116 \\
1 & 73.55 & 115 \\
1.25 & 91.94 & 114 \\
1.5 & 110.33 & 111 \\
1.75 & 128.71 & 107 \\
2 & 147.1 & 102 \\
2.25 & 183.88 & 91 \\
2.5 & 220.65 & 87 \\
5 & 376.75 & 33 \\
\hline \hline
\end{tabular}


TABLE 2

DRIFT CONTROL, $\Delta S$

\begin{tabular}{cccccc}
\hline \hline Storey & $\begin{array}{c}\boldsymbol{h i} \\
\mathbf{( m )}\end{array}$ & $\begin{array}{c}\Delta \mathbf{s} \\
(\mathbf{m m})\end{array}$ & $\begin{array}{c}\Delta \text { s displ./ } \\
\text { storey (mm) }\end{array}$ & $\begin{array}{c}\text { Requi- } \\
\text { site, } \Delta \mathbf{s} \\
\mathbf{( m m )}\end{array}$ & Note \\
\hline $\begin{array}{c}\text { Roof } \\
\text { 1st } \\
\text { floor }\end{array}$ & 3,6 & 2.653 & 1.7267 & 30 & OK \\
\hline \hline
\end{tabular}

TABEL 3.

DRIFT CONTROL, $\Delta_{\mathrm{M}}$

\begin{tabular}{cccccc}
\hline \hline Storey & $\begin{array}{c}\boldsymbol{h i} \\
(\mathbf{m})\end{array}$ & $\begin{array}{c}\text { Drift } \\
\mathbf{l i m i t} \Delta \mathbf{s} \\
\mathbf{( m m )}\end{array}$ & $\begin{array}{c}\text { Drift / } \\
\mathbf{s t o r e y} \Delta_{\mathbf{M}} \\
\mathbf{( m m )}\end{array}$ & $\begin{array}{c}\text { Requisit } \\
\mathbf{e ,} \Delta_{\mathbf{M}} \\
\mathbf{( m m}\end{array}$ & Note \\
\hline Roof & 3,6 & 2.653 & 6,5005 & 72 & OK \\
1st Floor & 3,6 & 0.956 & 2,3437 & 72 & OK \\
\hline \hline
\end{tabular}

TABLE 4.

SUMMARY OF PERFORMANCE POINT

Method

Performance

Point (m)

Spectrum Capacity Method

0,031

Displacement Coefficient Method

0,127

(FEMA 356)

An Improved Displacement

0,127

Coefficient Method (FEMA 440)

Ultimate Limit Performance

0,064 